\title{
EDUKASI MANFAAT DUKUNGAN SUAMI KEPADA IBU SELAMA PERSALINAN
}

DOI: https://doi.org/10.33024/jkpm.v4i4.3904

\author{
Mareta Bakale Bakoil ${ }^{1 *}$, Loriana L Manalor ${ }^{2}$, Martina Fenansia Diaz ${ }^{3}$, Veki \\ Edizon Tuhana ${ }^{4}$ \\ ${ }^{1-3}$ Poltekkes Kemenkes Kupang, ${ }^{4}$ Universitas Nusa Cendana Kupang \\ Disubmit: 24 Februari 2021 Diterima: 01 Maret 2021 Diterbitkan: 01 Agustus 2021
}

Email Korespondensi: thabakoil@gmail.com

\begin{abstract}
ABSTRAK
Dukungan suami selama kehamilan, persalinan dan persalinan diperlukan. Hasil penelitian menunjukkan bahwa $85,3 \%$ responden yang di dampingi selama proses persalinan mengalami proses persalinan yang lancar sehingga secara statistik disimpulkan bahwa ada hubungan antara pendampingan suami dengan kelancaran proses persalinan (Lailia dan Nisa, 2015). Sedangkan hasil penelitian Bakoil dan Diaz (2019) menunjukkan bahwa ada hubungan dukungan suami dalam persalinan terhadap lamanya proses persalinan di Kabupaten Timor Tengah Selatan tahun 2019. Tujuan yaitu untuk meningkatkan pengetahuan suami tentang dukungan kepada ibu selama persalinan. Kegiatan edukasi menggunakan materi penyuluhan, leaflet tentang suami siaga, kuesioner pre dan post test, diskusi dan tanya jawab. Kegiatan edukasi/penyuluhan kepada suami-suami sebanyak 15 orang. Sebelum penyuluhan peserta diberikan pre test dengan tujuan untuk mengetahui pengetahuan dan pemahaman tentang dukungan suami kepada ibu saat persalinan. Setelah pemberian edukasi/penyuluhan, dilanjutkan dengan proses tanya jawab dan post test. Peserta kegiatan sangat antusias dan terjadi peningkatan pengetahuan tentang manfaat dukungan suami selama persalinan.
\end{abstract}

Kata Kunci :dukungan, suami, persalinan

\section{ABSTRACT}

Husband's support during pregnancy, childbirth and delivery is needed. The results showed that $85.3 \%$ of respondents who were assisted during the labor process experienced a smooth labor process so that it was statistically concluded that there was a relationship between husband's assistance and the smoothness of the delivery process (Lailia and Nisa, 2015). Meanwhile, the results of research by Bakoil and Diaz (2019) show that there is a relationship between husband's support in childbirth and the length of the delivery process in South Central Timor Regency in 2019. The objective is to increase the husband's knowledge of support to the mother during childbirth. Educational activities using counseling materials, leaflets about standby husbands, pre and posttest questionnaires, discussions and questions and answers. Educational activities/outreach for husbands as many as 15 people. Prior to counseling, participants were given a pretest with the aim of knowing and understanding 
the husband's support for mothers during childbirth. After providing education/counseling, it is followed by a question and answer process and posttest. The activity participants were very enthusiastic and there was an increase in knowledge about the benefits of husband support during childbirth.

Keywords: support, husband, childbirth

\section{PENDAHULUAN}

Angka Kematian Ibu (AKI) menjadi salah satu indikator penting dalam menentukan derajat kesehatan masyarakat dan di Indonesia masing tergolong tinggi. Kematian ibu adalah kematian perempuan pada saat hamil atau kematian dalam kurun waktu 42 hari sejak terminasi kehamilan tanpa memandang lamanya kehamilan atau tempat persalinan, yakni kematian yang disebabkan karena kehamilannya atau pengelolaannya, tetapi bukan karena sebab-sebab lain seperti terjatuh, kecelakaan/100.000 kelahiran hidup. Salah satu target pembangunan Sustainable Development Goals (SDGs) adalah mengurangi kematian ibu hingga di bawah 70 per 100.000 kelahiran hidup, angka kematian balita 25 per 1.000 kelahiran hidup, dan angka kematian neonatal 12 per 1.000 kelahiran hidup pada tahun 2030 (Stalker, 2012). Kesehatan ibu mencakup seluruh kesehatan wanita usia subur (WUS) mulai dari pra kehamilan, kehamilan, persalinan dan kelahiran serta masa pasca partum (Kemenkes RI, 2017).

Angka Kematian Ibu di Indonesia tahun 2012 hasil Survey Demografi dan Kesehatan Indonesia (SDKI) yaitu 359 kematian ibu per 100.000 kelahiran hidup. Namun pada tahun 2016 AKI di Indonesia mengalami penurunan menjadi 305 per 100.000 kelahiran hidup (Kemenkes RI, 2017). Dari laporan Profil Dinas Kesehatan Kabupaten/Kota Se-Provinsi NTT Tahun 2017, pada tahun 2010-2015 AKI yang dilaporkan diprovinsi NTT mengalami penurunan dari 328/100.000 kelahiran hidup menjadi 93/100.000 kelahiran hidup. Sedangkan AKB turun dari 21.59/1.000 menjadi 20.22/1.000 kelahiran hidup (Dinas Kesehatan Provinsi NTT, 2017). Penyebab kematian ibu adalah perdarahan $(25,0 \%)$, persalinan kala II lama $(17,0 \%)$, infeksi $(13,0 \%)$, aborsi tidak aman $(13,0 \%)$, eklamsia $(12,0 \%)$, penyebab langsung lainnya $(8,0 \%)$, dan penyebab tidak langsung $(12,0 \%)$. Penyebab tidak langsung seperti malaria, anemia, HIV/AIDS, dan penyakit kardiovaskuler (Kemenkes RI, 2017).

Dukungan suami selama kehamilan, persalinan dan persalinan diperlukan. Kehadiran suami di samping istri membuat istri merasa lebih tenang dan lebih siap menghadapi proses persalinan (Musbikin, 2012). Sebaliknya apabila kurangnya dukungan suami selama kehamilan, persalinan, dan nifas dapat berbahaya. Hasil penelitian menunjukkan bahwa $85,3 \%$ responden yang di dampingi selama proses persalinan mengalami proses persalinan yang lancar sehingga secara statistik disimpulkan bahwa ada hubungan antara pendampingan suami dengan kelancaran proses persalinan (Lailia dan Nisa, 2015). Sedangkan hasil penelitian Bakoil dan Diaz (2019) menunjukkan bahwa ada hubungan dukungan suami dalam persalinan terhadap lamanya proses persalinan di Kabupaten Timor Tengah Selatan tahun 2019. Hal ini membuktikan bahwa dukungan suami sangat penting. 


\section{MASALAH}

Dukungan suami yang diberikan kepada istri merupakan bentuk nyata dari kepedulian, tanggung jawab suami dalam kehidupan istri serta anak-anaknya. Seberapa jauh pengetahuan masyarakat tentang dukungan suami dalam proses persalinan, masih perlu untuk sering dilakukan penyuluhan, mengingat banyak sekali manfaat dari dukungan yang diberikan suami kepada istri selama proses persalinan.

Pemecahan masalah yang ada di masyarakat berkaitan dengan manfaat dukungan suami selama proses persalinan, dapat direalisasikan melalui kegiatan Pengabdian Kepada Masyarakat berupa edukasi tentang dukungan suami. Edukasi tentang manfaat dukungan suami dapat memberikan tambahan pengetahuan dan pemahaman kepada masyarakat untuk diaplikasikan.

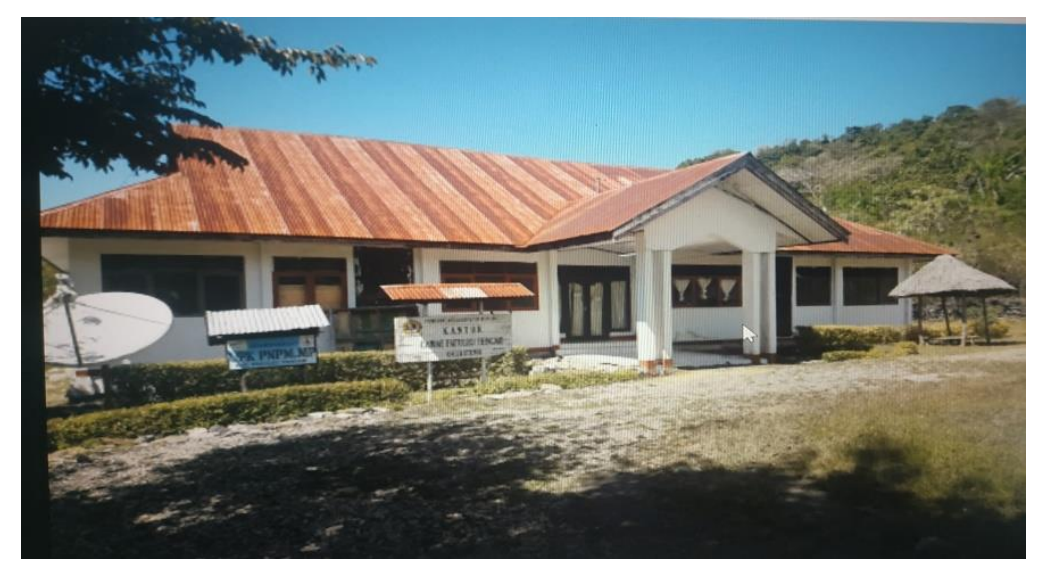

Gambar 1 Lokasi Pengabdian Masyarakat

\section{METODE}

\section{a. Tahap Persiapan}

1) Tim pengabdian masyarakat menyiapkan surat ijin pengabdian masyarakat, materi penyuluhan, kuesioner pre dan post test tentang pengetahuan suami terkait dengan dukungan suami selama proses persalinan, dengan 15 pertanyaan dan 2 (dua) pilihan jawaban "Benar dan Salah", leaflet dukungan suami, alat, bahan serta seluruh kelengkapan untuk kegiatan.

2) Pendekatan kepada Camat Fatuleu Tengah Kabupaten Kupang dengan mengirimkan surat permohonan ijin pelaksanaan kegiatan pengabdian masyarakat.

3) Pendekatan dengan Kepala Puskesmas Oelbiteno untuk membantu menginformasikan kepada mitra pengabdian masyarakat (suamisuami) terkait dengan rencana pelaksanaan kegiatan.

\section{b. Tahap pelaksanaan}

1) Tim ke lokasi pengabdian masyarakat dan memberikan edukasi/penyuluhan kepada suami-suami tentang dukungan kepada ibu selama persalinan.

2) Sebelum pemberian edukasi, tim memberikan kuesioner kepada suami-suami (pre test) dengan tujuan untuk mengetahui 
pengetahuan dan pemahaman tentang dukungan suami kepada ibu saat persalinan.

3) Setelah pemberian edukasi/penyuluhan, lakukan proses tanya jawab, diskusi dan post test.

\section{c. Evaluasi}

Kegiatan pengabdian masyarakat dilaksanakan sesuai jadwal yang ditentukan, berlangsung dengan baik. Materi disampaikan dengan baik dan menggunakan bahasa sederhana dan mudah dipahami mengingat peserta (suami-suami) kegiatan berasal dari berbagai latar belakang. Interaksi pemateri dan peserta dalam sesi diskusi dan tanya jawab yang dibagi kedalam dua sesi berlangsung dengan sangat baik. Pada akhir kegiatan, pemateri juga memberikan leaflet tentang suami siaga bagi semua peserta.
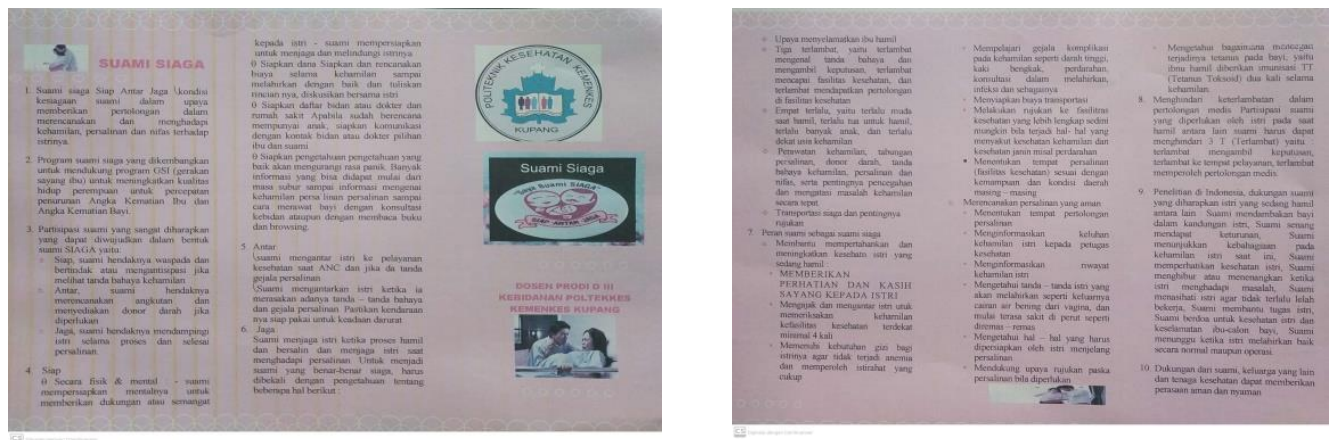

Gambar 2 Leaflet tentang suami siaga

\section{HASIL DAN PEMBAHASAN}

Kegiatan pengabdian masyarakat dilaksanakan di Desa Oelbiteno. Desa Oelbiteno merupakan salah satu desa model pembinaan tim pengerak (TP) PKK serta menjadi desa unggul di provinsi Nusa Tenggara Timur (NTT). (Laporan BPS, 2020). Kegiatan dilaksanakan hari kamis tanggal 05 November 2020, bertempat di Aula Kantor Camat Fatuleu Tengah. Kegiatan diawali dengan pembukaan oleh Sekretaris Camat Fatuleu Tengah dan juga di hadiri oleh Kepala Puskesmas Oelbiteno, Bidan Koordinator dan staf Puskesmas.

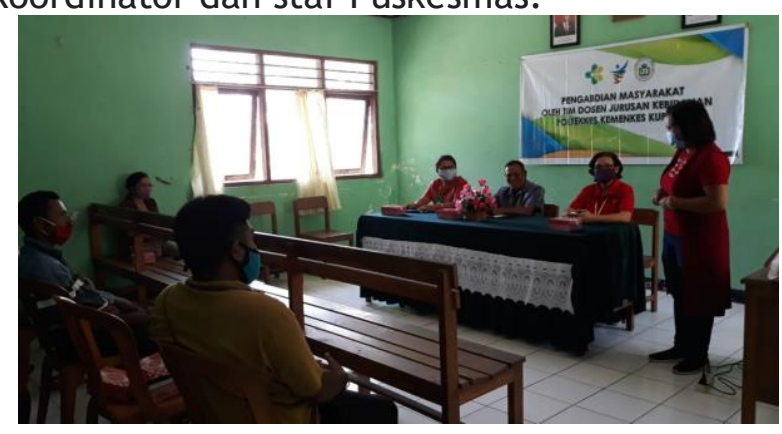



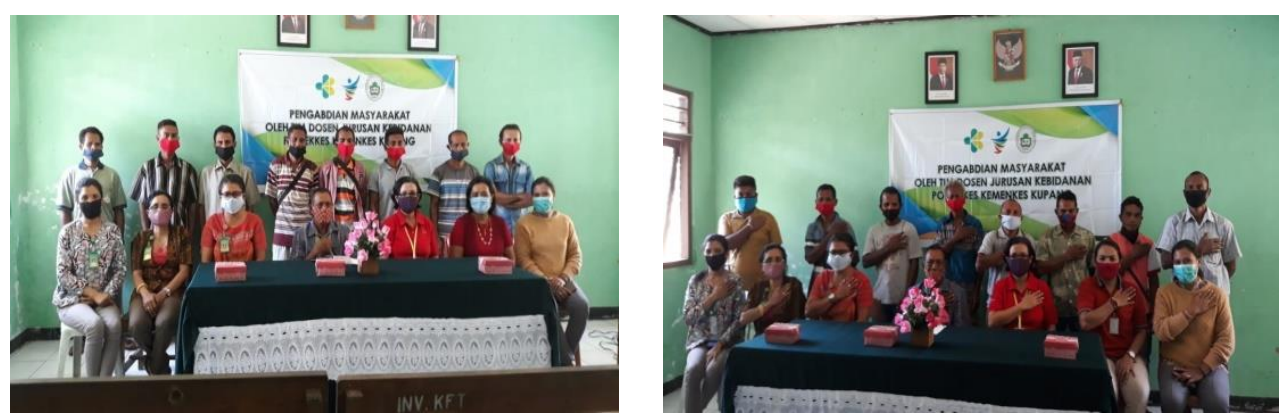

Gambar 3 Acara Pembukaan Kegiatan Pengabmas

Setelah acara pembukaan dilanjutkan dengan edukasi/penyuluhan tentang dukungan suami bagi ibu bersalin. Kegiatan penyuluhan di awali dengan penyampaian materi tentang dukungan suami oleh Tim pengabdian masyarakat dosen.
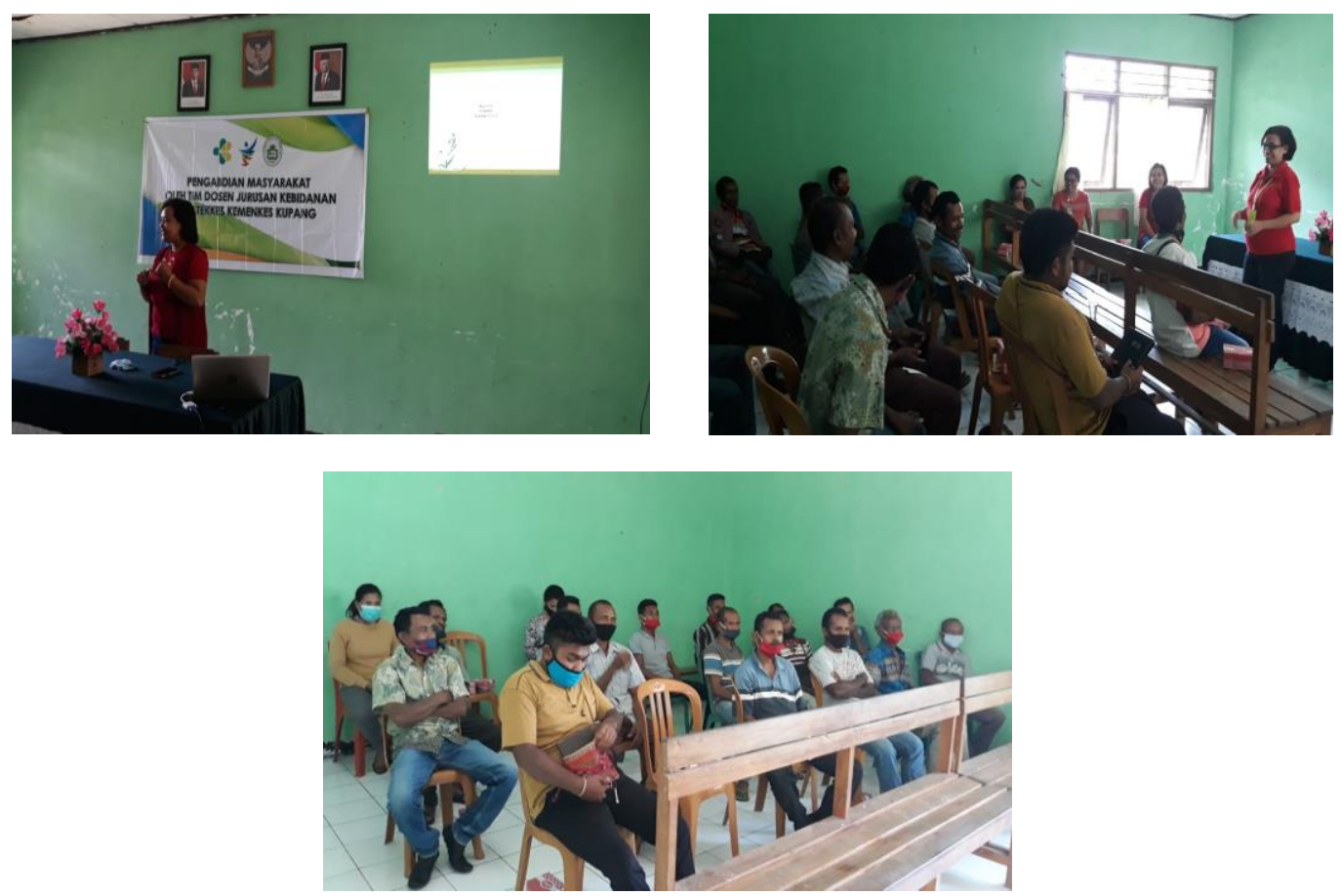

Gambar 4 Pemberian Materi tentang Dukungan Suami kepada Ibu selama Persalinan

Sosialisasi/penyuluhan menurut Kamus Besar Bahasa Indonesia berarti upaya memasyarakatkan sesuatu sehingga menjadi dikenal, dipahami, dihayati oleh masyarakat atau pemasyarakatan. Sosialisasi itu sendiri sangat penting adanya, karena bila tidak ada sosialisasi maka bisa dipastikan apapun tujuan yang kita maksudkan untuk diri kita sendiri ataupun untuk orang lain tidak akan tercapai (Riadi, 2020). Kegiatan sosialisasi yang dilakukan oleh tim pengabdian masyarakat dosen dengan melibatkan suami-suami dari ibu bersalin di Desa Oelbiteno, Kabupaten Kupang. Kegiatan sosialisasi tidak hanya menyampaikan informasi, tetapi juga mencari dukungan dari berbagai kelompok masyarakat. 
Syarat terjadinya sosialisasi pada dasarnya, sosialisasi memberikan dua kontribusi fundamental bagi kehidupan kita. Pertama, memberikan dasar atau pondasi kepada individu bagi terciptanya partisipasi yang efektif dalam masyarakat, dan kedua memungkinkan lestarinya suatu masyarakat karena tanpa sosialisasi akan hanya ada satu generasi saja sehingga kelestarian masyarakat akan sangat terganggu (Riadi, 2020).

Sosialisasi yang dilakukan bertujuan untuk memberikan penjelasan dan informasi kepada suami-suami tentang pentingnya dukungan yang diberikan oleh suami kepada ibu saat persalinan. Menurut konsep bahwa pada umumnya suatu aktivitas sosialisasi mempunyai tujuan sebagai berikut: 1) memperkenalkan apa yang akan di sampaikan. Sosialisasi diharapkan dapat menyampaikan pesan pada masyarakat yang dituju atau ditargetkan itu. Kemudian dengan demikian perlu dipilih cara yang sesuai dengan masyrakat yang ditargetkan itu; 2) untuk menarik perhatian. Aktivitas sosialisasi harus dikemas dalam bentuk yang menarik perhatian agar masyarakat tertarik dan menyimpan pesan yang disampaikan dalam memori pikiran mereka itu. Kemudian, cara yang dilakukan pada umumnya memberikan sponsor pada suatu acara tertentu menggunakan tokoh masyarakat setempat menonjolkan keunggulan dari program-program yang diperkenalkan itu; 3) tercapainya pemahaman. Sosialisasi yang direncanakan dengan baik akan memudahkan masyarakat memahami pesan yang disampaikan kepadanya itu. Kemudian pesan yang jelas dan penggunaan media yang tepat dan kemasan cerita yang menarik mampu menyampaikan pesan kepada pengguna secara cepat dan tepat; 4) perubahan sikap. Setelah sosialisasi dapat dipahami, organisasi mengharapkan suatu tanggapan dari calon terhadap sosialisasi tersebut itu; dan 5) tindakan. Tujuan akhir sosialisasi adalah mempertahankan keberadaan organisasi melalui peningkatan hasil yang dicapai akibat meningkatkan pengguna yang memanfaatkan barang/jasa yang ditawarkan organisasinya itu. Kemudian, oleh karena itu tujuan akhir sosialisasi adalah menimbulkan tindakan calon pengguna yang dituju untuk memanfaatkan barang/jasa yang di sosialisasikan (Riadi, 2020).

Sebelum pemberian materi dilakukan pre test untuk 15 orang peserta, dan selesai materi dilanjutkan dengan tanya jawab, diskusi dan post test. Pre test ini mempunyai maksud untuk mengetahui lebih awal pemahaman peserta tentang topik edukasi. Hasil pre dan posttest dapat dilihat pada tabel 1.

Tabel 1 Distribusi hasil pre test peserta di Desa Oelbiteno Kecamatan Fatuleu Tengah Kabupaten Kupang

\begin{tabular}{|c|c|c|c|c|}
\hline \multirow{2}{*}{ Kategori pengetahuan } & \multicolumn{2}{|c|}{ Pre Test } & \multicolumn{2}{|c|}{ Post Test } \\
\hline & $\mathrm{n}$ & $\%$ & $\mathrm{n}$ & $\%$ \\
\hline Baik (11-15) & 14 & 93,3 & 15 & 100 \\
\hline Cukup (8-10) & 1 & 6,7 & 0 & 0 \\
\hline Kurang (0-7) & 0 & 0 & 0 & 0 \\
\hline Total & 15 & 100 & 15 & 100 \\
\hline
\end{tabular}

Berdasarkan tabel 1 menunjukkan bahwa mayoritas peserta mempunyai pengetahuan yang baik tentang dukungan suami. Pencapaian tingkat pengetahuan peserta dari pre test dan post test mengalami peningkatan dan semua peserta (100\%) mempunyai pengetahuan dengan kategori baik, yang artinya bahwa suami-suami telah mengetahui tentang manfaat dukungan yang 
diberikan oleh suami kepada istri saat persalinan.

Pengetahuan adalah fakta, kebenaran atau informasi yang diperoleh melalui pengalaman atau pembelajaran disebut posteriori, atau melalui introspeksi disebut priori. Pengetahuan juga merupakan informasi yang diketahui atau disadari oleh seseorang (Binus University, 2020). Pengetahuan yang dimiliki suami tentang pentingnya dukungan mempunyai hubungan dengan pemberian dukungan kepada istri saat proses persalinan sehingga dapat mengurangi tingkat kecemasan ibu bersalin kala I (Sarwinanti \& Aristyawati, 2019). Hal ini juga disampaikan Cholifah et al., (2012) bahwa ada hubungan antara tingkat pengetahuan suami dalam pendampingan istri saat proses persalinan.

Peserta dalam kegiatan pengabdian masyarakat bervariatif. Beberapa peserta adalah merupakan kader posyandu. Kader posyandu mempunyai peran penting dalam kemajuan bidang kesehatan, salah satu nya kesehatan ibu, bayi dan balita di masyarakat. Informasi dan pengetahuan yang baik oleh kader posyandu menjadi bekal bagi kader untuk menyalurkan informasi kepada sasaran KIA yang ada di masyarakat. Pemberian pelatihan tentang kesehatan ibu, bayi dan balita dapat menigkatkan pengetahuan yang dapat digunakan sebagai langkah awal dalam memberikan penyuluhan dan membentuk keterampilan kader (Didah et al., 2019).

\section{KESIMPULAN}

Kesimpulan yang diperoleh setelah pelaksanaan kegiatan pengabdian masyarakat ini, adalah peserta kegiatan sangat antusias. Peningkatan pengetahuan tentang kesehatan dalam hal ini manfaat dukungan suami dalam proses sangat diperlukan guna meningkatkan kesehatan dan kesejahteraan ibu dan bayi. Oleh karena itu perlu dilakukan penyuluhan/edukasi serupa yang bersifat mudah diaplikasikan dan memberi nilai tambah bagi masyarakat.

Ucapan terima kasih disampaikan kepada Poltekkes Kemenkes Kupang yang telah mendukung pendanaan kegiatan pengabdian masyarakat ini.

\section{DAFTAR PUSTAKA}

Bakoil, M. B., Diaz, M. F. (2020). Pengaruh Pengambilan Keputusan, Dukungan Suami dan Faktor Budaya Terhadap Lamanya Proses Persalinan di Kabupaten Timor Tengah Selatan Tahun 2019. Jurnal Penelitian Kesehatan Suara Forikes. 11(November-Desember 2020), 107-111.

Binus University. (2020). Konsep Pengetahuan. Retrieved from https://onlinelearning.binus.ac.id.

Cholifah, N., Astuti, D., Setyaningrum, Y. (2012). Tingkat Pengetahuan Suami Dalam Pendampingan Istri Pada Saat Proses Persalinan di RB Wilayah Kabupaten Kudus Bulan Juni 2012. JIKK, 4(1), 50-59

Didah., Susanti, A.I., Elba, F. (2019). Upaya Peningkatan Pengetahuan Kader Posyandu Tentang Kesehatan Ibu Hamil, Bayi Dan Balita Di Wilayah Puskesmas Jatinangor Kecamatan Jatinangor Sumedang. Jurnal Kreativitas Pengabdian Kepada Masyarakat, 2(1), 64-72

Dinas Kesehatan Provinsi Nusa Tenggara Timur. (2015). Profil Kesehatan Provinsi NTT 2015. Kupang NTT

Kementerian Kesehatan RI. (2017). Riset Kesehatan Dasar (Riskesdas) 2017. 
Kementerian Kesehatan RI-Badan Penelitian dan Pengembangan Kesehatan, Jakarta

Lailia, I. N., Nisa, F. (2015). Pendampingan Suami terhadap Kelancaran Proses Persalinan di BPM Arifin S Surabaya. Jurnal Ilmiah Kesehatan, 8(1), 22-28

Musbikin, I. (2012). Persiapan Menghadapi Persalinan dari Perencanaan Kehamilan Sampai Mendidik Anak. Yogyakarta: Mitra Pustaka.

Riadi, M. (2020). Sosialisasi (Pengertian, Tujuan, Jenis, Proses dan Hambatan). Retrieved from https://www.kajianpustaka.com/2020/04

Sarwinanti., Aristyawati, R. (2019). Hubungan Dukungan Suami Dan Pengetahuan Tentang Persalinan Dengan Kecemasan Ibu Bersalin Kala I. Jurnal Health of Studies, 3(2), 97-105

Stalker, P. (2012). Millennium Development Goals. Menteri Negara Perencanaan Pembangunan Nasional-United Nations, Jakarta

............. Kamus Besar Bahasa Indonesia. [Online]. Tersedia di kbbi.kemdikbud.go.id/entri/religius. Diakses 10 November 2020 